
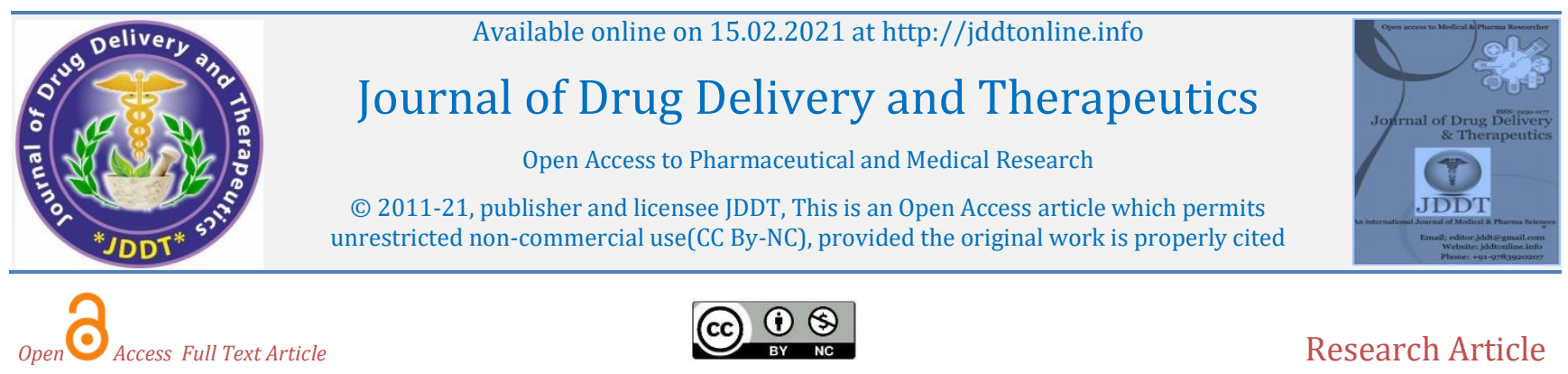

Research Article

\title{
Development of High Performance Thin Layer Chromatography Method for Quantitation of Gallic Acid in Normacid Syrup: A Poly Herbal Formulation
}

\author{
Shah Kinjal H1*, Makwana Rajeshree ${ }^{2}$ \\ ${ }_{1}^{1}$ Professor, B. Pharmacy College, Rampura, Gujarat, India \\ ${ }^{2}$ Assistant Professor, B. Pharmacy College, Rampura, Gujarat, India
}

\begin{tabular}{l} 
Article Info: \\
\hline Article History: \\
Received 06 Dec 2020; \\
Review Completed 22 Jan 2021 \\
Accepted 30 Jan 2021; \\
Available online 15 Feb 2021
\end{tabular}

*Address for Correspondence:

Dr. Shah Kinjal H, Professor, B. Pharmacy College, Rampura, Gujarat, India

\author{
Abstract
}

Normacid syrup consisiting of 17 ingredients, used in the treatment of hyperacidity and gastritis. Gallic acid is one of the phytoconstituent present in Normacid syrup- a poly herbal formulation. In the present study an attempt has been made to develop a HPTLC method for quantitative estimation of gallic acid in dried fruits used in formulations. This HPTLC method was found to be reproducible, accurate, precise and detect gallic acid at nanogram level. The developed HPTLC method would be an important tool in the quality control method of poly herbal formulation.

Keywords: HPTLC, Polyherbal, Gallic acid, Gastritis

\section{Cite this article as:}

Shah KH, Makwana R, Development of High Performance Thin Layer Chromatography Method for Quantitation of Gallic Acid in Normacid Syrup: A Poly Herbal Formulation, Journal of Drug Delivery and Therapeutics. 2021; 11(1-s):49-52 DOI:http://dx.doi.org/10.22270/jddt.v11i1-s.4546

\section{INTRODUCTION1-21}

The stomach normally secretes acid that is essential in the digestive process. This acid helps in breaking down the food during digestion. When there is excess production of acid in the stomach, it results in the condition known as acidity or APD. Normally, there are some protective mechanisms against acid, in the stomach and proximal intestine. But an imbalance between the protective mechanisms and the level of acid secretion can cause acidity ${ }^{1,2}$ Gastritis is an inflammation of the lining of the stomach, and has many possible causes. ${ }^{3,4}$ The main acute causes are excessive alcohol consumption or prolonged use of nonsteroidal antiinflammatory drugs such as aspirin or ibuprofen. Sometimes gastritis develops after major surgery, traumatic injury, burns, or severe infections. Gastritis may also occur in those who have had weight loss surgery resulting in the banding or reconstruction of the digestive tract. Chronic causes are infection with bacteria, primarily Helicobacter pylori. Certain diseases, such as pernicious anemia, chronic bile reflux, stress and certain autoimmune disorders can cause gastritis as well. The most common symptom is abdominal upset or pain. Other symptoms are indigestion, abdominal bloating, nausea, and vomiting. Some may have a feeling of fullness or burning in the upper abdomen.6,7,8,10 Pain in the upper abdomen is the most common symptom. Bloating and a feeling of fullness or burning in the upper abdomen is also signs of moderate gastritis. Severe gastritis presents pallor, sweating, rapid heart beat, feeling faint or short of breath, severe chest or stomach pain, vomiting large amounts of blood, or bloody or dark, sticky, foul-smelling bowel movements. ${ }^{15-20}$ Tests for blood cell count, H. pylori, and pregnancy; and liver, kidney, gallbladder, and pancreas functions, may be ordered. Urinalysis may be used, or a stool sample taken, to look for blood in the stool. X-rays may be ordered, as well as ECGs. If none of these tests are able to be used for diagnosis, the patient may be recommended to a gastroenterologist. An endoscopy may be performed, where a flexible probe with a camera on the end is sent into the stomach to check for stomach lining inflammation and mucous erosion. At the same time, a stomach biopsy may be taken to test for gastritis and a variety of other conditions. ${ }^{15}$ 20 Normacid syrup is a polyherbal formulation and works as a natural antacid. Antacid perform a neutralization reaction, i.e. they buffer gastric acid, raising the $\mathrm{pH}$ to reduce acidity in the stomach. When gastric hydrochloric acid reaches the nerves in the gastrointestinal mucosa, they signal pain to the central nervous system. This happens when these nerves are exposed, as in peptic ulcers. The gastric acid may also reach ulcers in the esophagus or the duodenum.

\subsubsection{Dosage}

Syrup: $10 \mathrm{ml}$ twice a day or as directed by physician

\subsubsection{Indications}

Gastritis

Acidity

Hyperacidity 
The Only True Acid Normaliser. As Normacid not only neutralizes the excess acid but also normalizes acid secretion.

\subsubsection{Composition of Normacid syrup}

\begin{tabular}{|l|l|c|}
\hline $\begin{array}{l}\text { Name of } \\
\text { ingredient }\end{array}$ & Parts Used & $\begin{array}{l}\text { Label claim } \\
\text { mg/10ml }\end{array}$ \\
\hline Adumber & Bark & 40 \\
\hline Dhamasa & Whole Plant & 30 \\
\hline Khas & Root & 5 \\
\hline Chandan & Wood & 5 \\
\hline Kalmegh & Whole Plant & 6 \\
\hline Neem & Bark & 8 \\
\hline Harde & Bark & 20 \\
\hline Behda & Bark & 15 \\
\hline Amla & Fruit & 20 \\
\hline Kadupatol & Whole Plant & 8 \\
\hline Ardusi & Flower & 8 \\
\hline Gaduchi & Whole Plant & 8 \\
\hline Pittapapdo & Whole Plant & 8 \\
\hline Shaukik bhasma & ----- & 25 \\
\hline Kapardika bhasma & ----- & 25 \\
\hline Praval bhasma & ------ & 10 \\
\hline
\end{tabular}

\section{MATERIALS AND METHOD}

HPTLC finger-printing of raw material and finished product and quantitative determination of gallic acid.

HPTLC is the most simple separation technique available today which gives better precision and accuracy with extreme flexibility for various steps (stationary phase, mobile phase, development technique and detection). The HPTLC was carried out using a Hemilton $100 \mu \mathrm{l}$ HPTLC syringe, Camag Linomat V automatic spotting device, Camag twin trough chamber, Camag TLC Scanner-3, WINCAT integration software, aluminium sheet precoated with Silica Gel 60F254(Merck), $0.2 \mathrm{~mm}$ thickness. HPTLC finger printing technique is useful to identify and to check the purity of raw herbal extracts as well as finished product. Hence forth it is very useful tool in standardizing process of raw herbal extracts and finished products.

\section{Steps involved in HPTLC analysis}

- Selection of plate and adsorbent: Precoated aluminium plates with Silica Gel 60F254 (E. Merck, India) of $10 \times 10$ $\mathrm{cm}$ and $0.2 \mathrm{~mm}$ thickness, were used for the detection. The plates were pre-washed by methanol and activated at $60^{\circ} \mathrm{C}$ for $5 \mathrm{~min}$ prior to chromatography.

- Sample solution: Accurately weighted $20 \mathrm{mg}$ of extract of Adhatoda vasica root was taken, dissolved in methanol and transferred to a $10 \mathrm{ml}$ volumetric flask. The volume made up to the mark with Methanol. The volume made up to the mark with Methanol.

- Application of sample: Sample application is the most critical step for obtaining good resolution for quantification in HPTLC. The automatic application devices are preferable. The most recent automatic device "CAMAG LINOMAT V" was used to apply 1 band of $6 \mathrm{~mm}$ width with different concentration of all the extracts and marker solution also.

- Development: The plate was developed in CAMAG glass twin-through chamber $(10-10 \mathrm{~cm})$ previously saturated with the solvent for $60 \mathrm{~min}$ (temperature $25.2^{\circ} \mathrm{C}$, relative humidity 40\%). The development distance was $8 \mathrm{~cm}$. Subsequently scanning was done. The mobile phase or solvent system for all the raw herbs, raw ingredients, marker compound which is given in the Table 1.

Table 1. Solvent system for plant, extract of Normacid Syrup

\begin{tabular}{|c|l|l|}
\hline Sr No & \multicolumn{1}{|c|}{ Sample } & \multicolumn{1}{c|}{ Solvent system } \\
\hline 1 & Gallic acid, Neem, & Toluene: Ethyl acetate: \\
& Amla, Behda, Harde & Formic acid: Methanol \\
& & $(6: 6: 1.6: 0.4)$ \\
\hline
\end{tabular}

- Detection: The plate was scanned at UV $366 \mathrm{~nm}$ and 254 nm using CAMAG TLC Scanner-3 and LINOMAT-V. Rf value of each compound which were separated on plate and data of peak area of each band was recorded.

\section{RESULT AND DISCUSSION}

\section{Determination of Gallic acid by HPTLC}

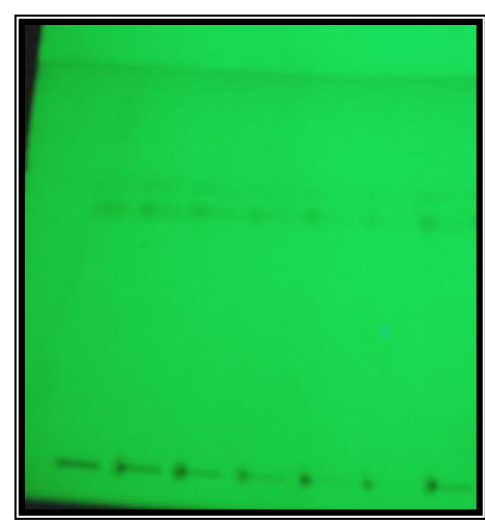

HPTLC plate of Gallic acid

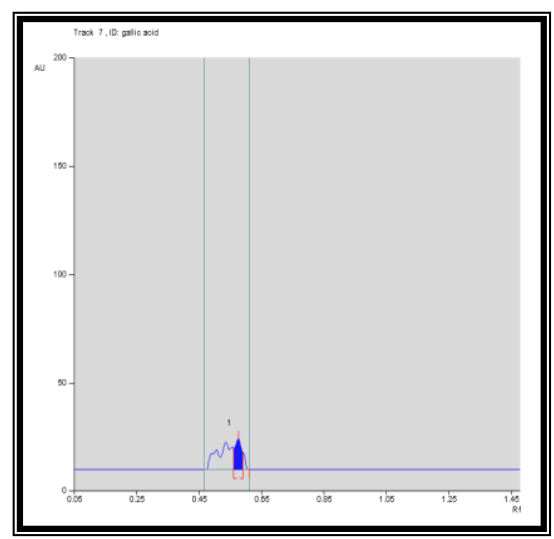

HPTLC chromatogram of Gallic acid

Track 1: $1 \mu \mathrm{g} / \mathrm{ml}$ of Gallic acid marker; Track 2: $2 \mu \mathrm{g} / \mathrm{ml}$ of Gallic acid marke; Track 3: $3 \mu \mathrm{g} / \mathrm{ml}$ of Gallic acid marker; Track 4: 4 $\mu \mathrm{g} / \mathrm{ml}$ of Gallic acid marke; Track 5: $5 \mu \mathrm{g} / \mathrm{ml}$ of Gallic acid marker; Track 6: $6 \mu \mathrm{g} / \mathrm{ml}$ of Gallic acid marker; Track 7: $7 \mu \mathrm{g} / \mathrm{ml}$ of Gallic acid marker 


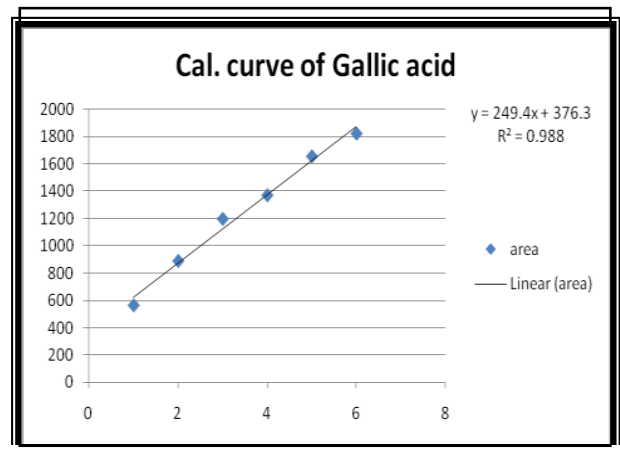

Calibration curve for Gallic acid

The peak areas of Gallic acid for $(1 \mu \mathrm{g} / \mathrm{ml}-7 \mu \mathrm{g} / \mathrm{ml})$ concentration were recorded. Calibration curve was prepared by plotting peak areas of Gallic acid against concentration. The results showed linearity and correlation coefficient within the range of concentration $(1 \mu \mathrm{g} / \mathrm{ml}-$

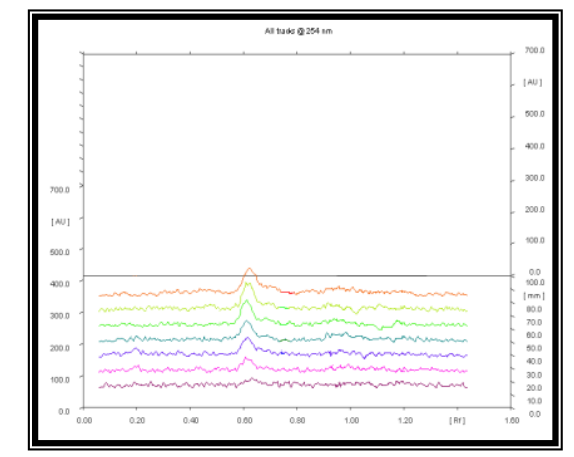

3D image of the Gallic acid

$5 \mu \mathrm{g} / \mathrm{ml}$ ). There was good correlation between peak area and the corresponding concentration of Gallic acid as shown in figure of Calibration curve for Gallic acid. The best fitting liner equation was $\mathrm{y}=249.4 \mathrm{X}+376.3\left(\mathrm{R}^{2}=0.988\right)$

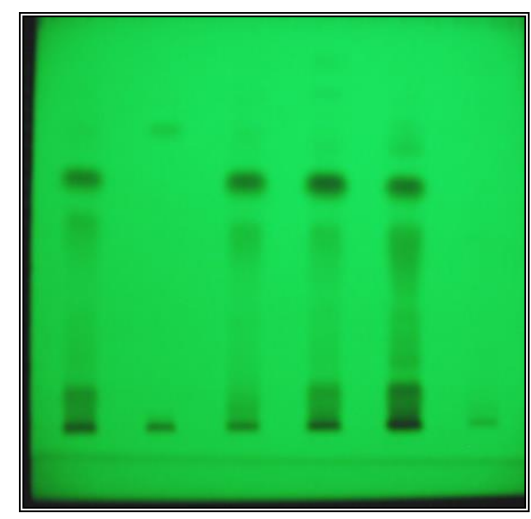

HPTLC plate of Gallic aci containing extract $\&$ formulation

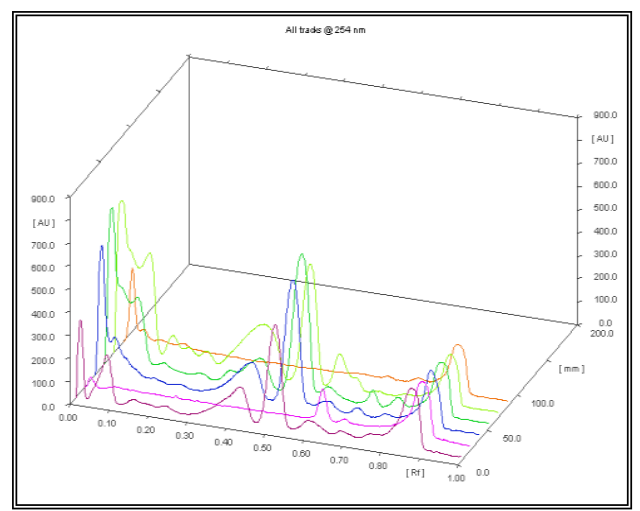

Three-D image of Gallic acid containing extract and formulation.

Track 1: $10 \mu \mathrm{g} / \mathrm{ml}$ of Normacid Formulation; Track 2: $4 \mu \mathrm{g} / \mathrm{ml}$ of Gallic acid marker; Track 3: $10 \mu \mathrm{g} / \mathrm{ml}$ of Amla extract; Track 4: $10 \mu \mathrm{g} / \mathrm{ml}$ of Behda extract; Track 5: $10 \mu \mathrm{g} / \mathrm{ml}$ of Harde extract;Track 6: $10 \mu \mathrm{g} / \mathrm{ml}$ of Neem extract

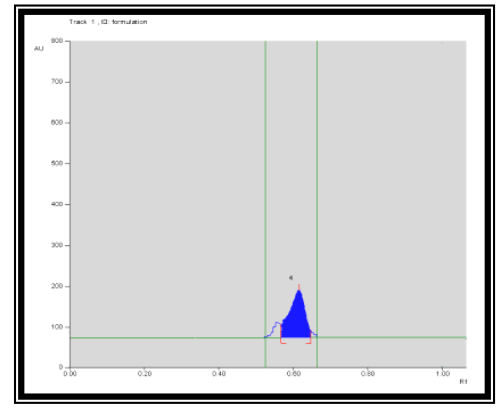

(A)

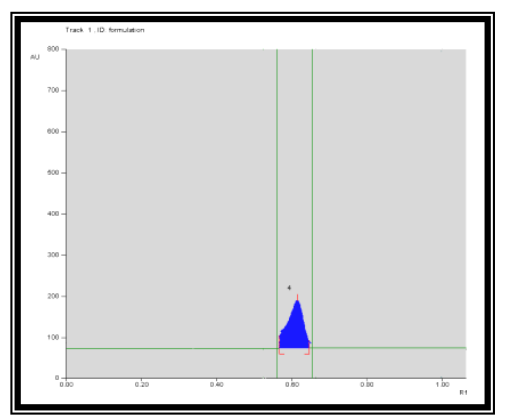

(D)

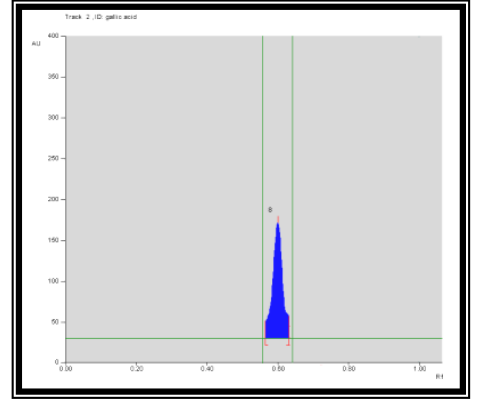

(B)

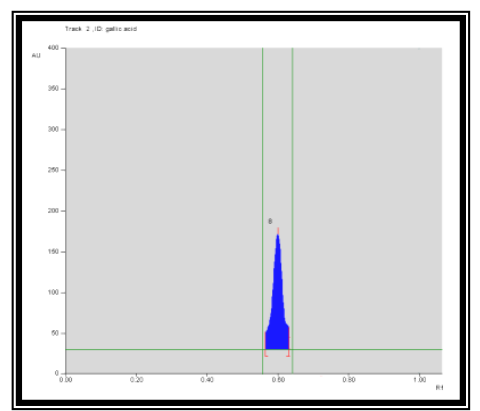

(E)

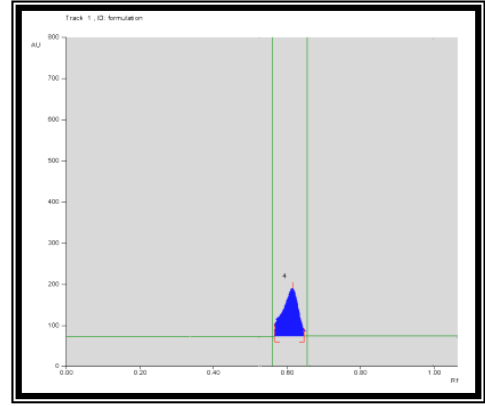

(C)

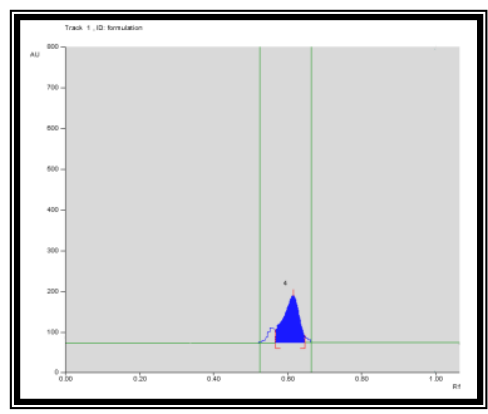

(F)

Chromatograms of Gallic acid, extract and formulation. 
A. Track 1: Chromatogram of Normacid Formulation; B. Track 2: Chromatogram of Gallic acid marker; C. Track 3: Chromatogram of Amla extract; D. Track 4: Chromatogram of Behda extract; E. Track 5: Chromatogram of Harde extract; F. Track 6: Chromatogram of Neem extract

Table 2. Peak table of chromatogram of Gallic acid, extracts and formulation

\begin{tabular}{|l|c|c|c|c|}
\hline & Peak & Max. Rf & Peak Area & Gallic acid mcg/ml \\
\hline Normacid & 1 & 0.58 & 1840.6 & 2.35 \\
\hline Gallic acid & 1 & 0.60 & 2253.9 & --- \\
\hline Amla & 1 & 0.59 & 1096.2 & 2.1 \\
\hline Behda & 1 & 0.60 & 1902.5 & 2.8 \\
\hline Harde & 1 & 0.59 & 1096.2 & 2.4 \\
\hline Neem & 1 & 0.60 & 1902.5 & \\
\hline
\end{tabular}

\section{SUMMARY AND CONCLUSION:}

Stationary phase Silica gel TLC plate and mobile phase toluene: ethyl acetate: formic acid: methanol (6:6:1.4:0.6) had given good separation of Gallic acid at $\mathrm{R}_{\mathrm{f}}=0.60$. The calibration curve of Gallic acid was found to be linear dependent on the concentration against area. The best fitting line equation was $\mathrm{y}=249.4 \mathrm{X}+376.3 . \mathrm{R}^{2} 0.988$ indicated good linearity between concentration and peak area in table 5.10 . Gallic acid content in the methanolic extract of Amla, Behda, Harde, Neem and Normacid formulation by the proposed HPTLC method was found to be $2.1 \mathrm{mcg} / \mathrm{ml}, 2.4 \mathrm{mcg} / \mathrm{ml}$, $2.8 \mathrm{mcg} / \mathrm{ml}, 2.4 \mathrm{mcg} / \mathrm{ml}$ and $2.35 \mathrm{mcg} / \mathrm{ml}$ respectively. The identity of the Gallic acid band in the sample extract solution was confirmed by overlaying the UV absorption spectrum of the sample with that from the reference standard of Gallic acid, using the Camag TLC scanner 3.

\section{REFERENCES}

1. Quality control methods for medicinal plant materials; World Health Organization; Geneva; A.I.T.B.S Publishers and distributers; Delhi.

2 www.healthorchid.com/content/consumer/acidity_m.asp

3. http://acidity.name/

4. http://www.umm.edu/altmed/articles/gastritis-000067.htm.

5. http://www.merck.com/mmpe/sec02/ch013/ch013c.html.

6. "Gastritis". National Digestive Diseases Information Clearinghouse (National Institute of Diabetes and Digestive and Kidney Diseases). December 2004.

http://digestive.niddk.nih.gov/ddiseases/pubs/gastritis/.

7. "Gastritis: Diagnostic Tests for Gastritis". Wrong Diagnosis. December 302008.

http://www.wrongdiagnosis.com/g/gastritis/intro.htm.
8. http://www.webmd.com/digestive-disorders/digestivediseases-gastritis.

9. Wolff G. "Effect of alcohol on the stomach Gastroenterol J 1989; 49(2):45-9.

10. Dajani EZ and Islam K (August 2008). "Cardiovascular and gastrointestinal toxicity of selective cyclo-oxygenase-2 inhibitors in man" (PDF). J Physiol Pharmacol. 2006; 59 Suppl 2:117-33. Siegelbaum, Jackson

11. "Gastritis". Jackson Siegelbaum Gastroenterology. http://www.gicare.com/pated/ecdgs46.htm

12. http://www.mayoclinic.com/health/gastritis/DS00488/DSECTI $\mathrm{ON}=$ causes

13. http://www.emedicinehealth.com/gastritis/page3_em.htm.

14. http://www.emedicinehealth.com/gastritis/page3_em.htm

15. Boparai V, Rajagopalan J and Triadafilopoulos G. "Guide to the use of proton pump inhibitors in adult patients". Drugs 2008; 68(7):925-47. doi:10.2165/00003495-200868070-00004..

16. http://www.cnn.com/HEALTH/library/DS/00488.html.

17. http://www.emedmag.com/html/pre/gic/consults/071503.asp.

18. Cullen DJ, Hawkey GM and Greenwood DC, "Peptic ulcer bleeding in the elderly: relative roles of Helicobacter pylori and nonsteroidal anti-inflammatory drugs". Gut 1997; 41(4):459-62.

19. "Peptic Ulcer: Peptic Disorders: Merck Manual Home Edition". http://www.merck.com/mmhe/sec09/ch121/ch121c.html.

20. Wachirawat W, Hanucharurnkul S, Suriyawongpaisal P, et al. "Stress, but not Helicobacter pylori, is associated with peptic ulcer disease in a Thai population". J Med Assoc Thai 2003; 86(7):672-85.

21. Ulcer, Diagnosis and Treatment - CDC Bacterial, Mycotic Diseases.

22. Anwar J, Farah M. Aslam M. A., Jafri S. Singh and Kalim Javed. "Plants with anti-ulcer activity." Recent progress of medicinal plants; 10:127-147. 